\title{
The owners of new passenger vehicles: some empirical findings on post-purchase patronage regarding servicing and repairs
}

\author{
C.Boshoff* \\ Department of Business Economics, Vista University, Private Bag X613, Port Elizabeth, 6000 Republic of South Africa \\ P.J. du Plessis \\ School of Business Leadership, University of South Africa, P.O. Box 392, Pretoria, 0001 Republic of South Africa \\ Accepted 6 February 1989
}

\begin{abstract}
Despite concern among motor vehicle manufacturers about the relationship between their franchised dealers and new vehicle owners regarding servicing/repairs, very little empirical research has been done to investigate the post-purchase perceptions of new vehicle owners. Research studies conducted in America found that the expiry of the warranty on a new motor vehicle resulted in a major shift away from franchised dealers for servicing/repairs once the warranty had expired and that the older the vehicle became, the higher the probability that it would not be serviced by a franchised dealer. Information gathered from a random sample of new vehicle owners suggests that these conclusions also hold true for the South African situation, despite a high degree of satisfaction expressed with under-warranty servicing.
\end{abstract}

\begin{abstract}
Nieteenstaande kommer by motorvervaardigers oor die verhouding tussen hul agentskaphouers en nuwevoertuigeienaars wat herstel- en versieningsdienste aan betref, is min empiriese navorsing nog gedoen om die na-aankoop persepsies van nuwe-voertuigeienaars te ondersoek. Navorsing wat in Amerika gedoen is, het bevind dat ' $n$ aansienlike aantal nuwe-voertuigeienaars nie langer die agentskaphouer ondersteun nie en dat hoe ouer ' $n$ voertuig is, hoe minder is die kanse dat 'n agentskaphouer wel versienings- en herstelwerk aan die voertuig sal doen. Inligting bekom van 'n ewekansige steekproef nuwe-voertuigeienaars dui daarop dat hierdie afleidings ook in die Suid-Afrikaanse situasie geld, nieteenstaande 'n hoë mate van tevredenheid met dienslewering terwyl die voertuig nog onder waarborg is.
\end{abstract}

* To whom correspondence should be addressed

\section{Introduction}

Automobile repair services is a topic that has received a fair amount of attention in marketing research literature. Biehal (1983: 82-91), for instance, investigated consumers' prior experiences and perceptions in auto repair choice, whereas Martilla \& James (1977: 77-79) used motor repair service customers to illustrate a technique for measuring attribute importance and performance in evaluating the elements of a marketing programme. In earlier years, Richardson \& Fogg (1970), Crandall (1970) and Pashigian (1961) analysed the automobile repair market in terms of patronage and market share. They concluded:

- that a high percentage of new vehicle owners shift their patronage to so-called independent workshops for servicing/repairs once the warranty has expired, and

- that the older the vehicle is, the higher the probability that it will not be serviced/repaired by a franchised dealer, but rather by a so-called independent workshop ${ }^{1}$.

However, these studies have been mainly of American origin. South African research on the topic has been limited. The only attention it has received generally has been as part of consumer buying behaviour studies where its importance as evaluation criterion in the decision to buy a particular passenger vehicle, has been evaluated (Rousseau, 1977; Du Plessis. 1986). In one of the few attempts to study motor repair services per se, a comparison was made between the perceptions of the customers of franchised dealers and those of the customers of independent workshops with regard to the various elements of a repair service (Boshoff, 1986: 196-201).

Despite the fact that two leading South African manufacturers estimate the retention rate of their repair service customers after the expiry of the warranty on new vehicles at below 30\% (Boshoff, 1986: 196), no research in South Africa has been done to investigate the post-purchase perceptions and patronage behaviour of the owners of new passenger vehicles.

\section{Objectives}

This study investigated the following with regard to the owners of new passenger vehicles:

- whether a franchised dealer of the manufacturer of the vehicle is patronized for servicing/repairs while the vehicle is under warranty;

- whether owners of new passenger vehicles are satisfied with the service received from these dealers; and

- the extent to which patronage for servicing/repair is shifted away from dealerships of the manufacturer once the warranty has expired.

An attempt was further made to establish whether the theory suggested (Pashigan, 1961) that the age of a vehicle has an inverse relationship to the probability of servicing/repairs at a franchised dealer, holds true. The relationship between satisfaction with service received 
from franchised dealers and (i) the model of the vehicle and (ii) the price of the vehicle was also investigated.

\section{Methodology}

Questionnaires were mailed to a stratified random sample of 3000 owners of new vehicles. Address lists of consumers who bought a new passenger vehicle during 1985 and 1986 from six of the seven motor vehicle manufacturers still active in the South African motor vehicle market, served as sampling frame. The sample was stratified according to the market share of each manufacturer in 1986, after the one manufacturer who did not wish to participate was excluded. The actual market share in 1986, adjusted market share, stratified sample size, actual number of responses per manufacturer, and percentage response rate per manufacturer are shown in Table 1 . These reveal a relatively high response rate from owners of Volkswagen products and a relatively low response rate from Nissan owners. However, these variances are not considered to be of such a magnitude that it would have a negative influence on the validity of results obtained.

The demographic characteristics of the respondent group is illustrated in Table 2. These reveal that 657 usable questionnaires were received, representing a response rate of $21,9 \%$. The majority of respondents $(78,8 \%)$ were male, reported on vehicles in the R10 $000-\mathrm{R} 19999$ price range $(58,8 \%)$, and the warranty of the vehicles of $63,6 \%$ of respondents had expired. The age distribution of respondents is fairly even throughout the various categories.

\section{Results}

It is often assumed that owners of new passenger vehicles comply with the stipulation of the warranty that all servicing/repairs should be conducted by a franchised dealer of the manufacturer. This has not been

Table 1 Response rate per manufacturer

\begin{tabular}{lcccccc}
\hline & $\begin{array}{c}1986 \\
\text { Market } \\
\text { share }\end{array}$ & $\begin{array}{c}\text { Adjusted } \\
\text { market }\end{array}$ & & & \multicolumn{2}{c}{ Responses } \\
\cline { 5 - 7 } & $(\%)$ & share $^{1}$ & Sample & $(n)$ & $\begin{array}{c}\% \text { of } \\
\text { sample }\end{array}$ \\
\hline Toyota & 26,01 & 29,76 & 893 & 159 & 24,4 \\
Samcor & 20,70 & 23,68 & 710 & 130 & 20,0 \\
Volkswagen & 17,38 & 19,87 & 596 & 247 & 37,9 \\
Mercedes Benz & 11,16 & - & - & - & - \\
Delta & 8,00 & 9,15 & 275 & 46 & 7,1 \\
Nissan & 7,82 & 8,94 & 268 & 16 & 2,5 \\
BMW & 7,52 & 8,60 & 258 & 53 & 8,1 \\
Other & 1,41 & - & - & - & - \\
& 100,0 & 100,0 & 3000 & $651^{2}$ & 100,0 \\
& & &
\end{tabular}

\footnotetext{
${ }^{1}$ Mercedes Benz was not prepared to participate in the study while manufacturers who were no longer active in the South African market were excluded.

${ }^{2}$ Six respondents did not indicate the manufacturer of their vehicle.
}

Table 2 Demographic characteristics of respondent group

\begin{tabular}{|c|c|c|}
\hline \multicolumn{3}{|l|}{ Sex } \\
\hline Male & 518 & 78,8 \\
\hline Female & 137 & 20,9 \\
\hline \multirow[t]{2}{*}{ No response } & 2 & 0,3 \\
\hline & 657 & 100,0 \\
\hline \multicolumn{3}{|l|}{ Price range } \\
\hline$<10000$ & 23 & 3,5 \\
\hline $10000-19999$ & 386 & 58,8 \\
\hline $20000-29999$ & 174 & 26,5 \\
\hline $30000+$ & 70 & 10,7 \\
\hline \multirow[t]{2}{*}{ No response } & 4 & 0,6 \\
\hline & 657 & 100,1 \\
\hline \multicolumn{3}{|l|}{ Warranty expired } \\
\hline Yes & 418 & 63,6 \\
\hline \multirow[t]{2}{*}{ No } & 239 & 36,4 \\
\hline & 657 & 100,0 \\
\hline \multicolumn{3}{|l|}{ Age } \\
\hline$<20$ & 5 & 0,8 \\
\hline $20-29$ & 102 & 15,5 \\
\hline $30-39$ & 177 & 26,9 \\
\hline $40-49$ & 156 & 23,7 \\
\hline $50-59$ & 111 & 16,9 \\
\hline $60+$ & 105 & 16,0 \\
\hline \multirow[t]{2}{*}{ No response } & 1 & 0,2 \\
\hline & 657 & 100,0 \\
\hline
\end{tabular}

Table 3 Institutions patronized while vehicle under warranty

\begin{tabular}{lrr}
\hline Institution & Number \% of total \\
\hline Dealership of manufacturer & 623 & 94,8 \\
Dealership of competing manufacturer & 2 & 0,3 \\
Independent workshop & 15 & 2,3 \\
Do own servicing/repairs & 8 & 1,2 \\
'Backyard mechanic' & 2 & 0,3 \\
No specific dealer/garage & 1 & 0,2 \\
No response & 6 & 0,9 \\
& 657 & 100,0 \\
\hline
\end{tabular}

empirically tested in South Africa before, but Table 3 shows that it is indeed the case.

According to Table $3,94,8 \%$ of respondents patronize a franchised dealer of the manufacturer for servicing/ repairs while the vehicle is under warranty.

The satisfaction of consumers who patronize(d) the franchised dealers of manufacturers was also measured. Table 4 shows that $80,6 \%$ of those new vehicle owners who patronize(d) franchised dealers while the vehicle is/ was under warranty are/were satisfied with the service received.

Richardson \& Fogg (1970: 216) found that in the 
Table 4 Satisfaction levels of respondents who patronize(d) franchised dealers of manufacturers

\begin{tabular}{lrr}
\hline Satisfaction level & \multicolumn{2}{c}{ Number \% of total } \\
\hline Satisfied & 502 & 80,6 \\
Indifferent & 51 & 8,2 \\
Dissatisfied & 67 & 10,8 \\
No response & 3 & 0,5 \\
& $623^{1}$ & 100,1 \\
\hline
\end{tabular}

${ }^{1}$ Only the satisfaction levels of respondents who patronize(d) franchised dealers are reported

Table 5 Institution patronized during period one year after expiry of warranty

\begin{tabular}{lrr}
\hline Institution & \multicolumn{2}{c}{ Number \% of total } \\
\hline Dealership of manufacturer & 304 & 72,7 \\
Dealership of competing manufacturer & 4 & 1,0 \\
Independent workshop & 42 & 10,0 \\
Do own services/repairs & 41 & 9,8 \\
Backyard mechanic & 11 & 2,6 \\
No specific dealer/garage & 4 & 1,0 \\
Haven't decided yet & 9 & 2,2 \\
No response & 3 & 0,7 \\
Total & 418 & 100,0 \\
\hline
\end{tabular}

United States of America a sizeable proportion of car owners shift their service business to non-dealer service organizations once the warranty period expires. An attempt was made to establish if the same applies to South African new vehicle owners. The results appear in Table 5.

Table 5 reveals that $72,7 \%$ of the 418 respondents whose warranty have expired still use a franchised dealer of the manufacturer during the first year after expiry. Compared with Table 3 it represents a decline of $22,1 \%$ which is significant at the 0,05 level of confidence (see Table 8).

To further investigate the patronage behaviour of the owners of new passenger vehicles immediately after the

Table 6 Institution to be patronized after expiry of warranty

\begin{tabular}{lrr}
\hline Institution & Number \% of total \\
\hline Dealership of manufacturer & 170 & 71,1 \\
Dealership of competing manufacturer & 2 & 0,8 \\
Independent workshop & 29 & 12,1 \\
Do own services/repairs & 22 & 9,2 \\
Backyard mechanic & 4 & 1,7 \\
No specific dealer/garage & 2 & 0,8 \\
Haven't decided yet & 10 & 4,2 \\
Total & 239 & 100,0 \\
\hline
\end{tabular}

expiry of the warranty, respondents whose warranty have not yet expired, were asked which institution they intend to patronize after expiry (Table 6).

Table 6 reveals that $71,1 \%$ of respondents intend to patronize a franchised dealer of the manufacturer after expiry of warranty, which seems to confirm the findings revealed in Table 5.

Pashigian (1961: 245-249) found that the probability that a car will be serviced by a franchised dealer decreases as the age of the car increases. An attempt was made to establish if this finding holds true in the South African situation. As the selection of a representative sample of vehicle owners whose vehicles were of varying ages was impossible, all respondents were asked what their intentions regarding patronizing would be when the warranty on the vehicle had expired, in the case, firstly, of vehicles less than five years old and, secondly of vehicles more than five years old. Although this method of information gathering might not be completely sound scientifically, studies where future purchasing intensions were studied have been reported (Wise \& Cox, 1980; Humphreys \& Kasulis, 1981) and it does give some indication of consumer perception and possible patronage behaviour ${ }^{2}$. Results of responses are shown in Table 7.

Table 7 shows that of the 642 respondents who indicated that they would still possess their vehicles when they were less than five years old, $64,8 \%$ intend to patronize a franchise dealer during this period. Table 7 also reveals that of the 390 respondents who hope to still possess their vehicles when they are more than five years old, only $50,3 \%$ indicated that they would patronize a

Table 7 Institution to be patronized during future time periods ${ }^{1}$

\begin{tabular}{|c|c|c|c|c|}
\hline \multirow[b]{3}{*}{ Institutions } & \multicolumn{4}{|c|}{ Time period } \\
\hline & \multicolumn{2}{|c|}{$\begin{array}{c}\text { Vehicle }<5 \\
\text { years old }\end{array}$} & \multicolumn{2}{|c|}{$\begin{array}{l}\text { Vehicle 5+ } \\
\text { years old }\end{array}$} \\
\hline & $(n)$ & $\%$ of $(n)$ & $(n)$ & $\%$ of $(n)$ \\
\hline Dealership of manufacturer & 416 & 64,8 & 196 & 50,3 \\
\hline $\begin{array}{l}\text { Dealership of competing } \\
\text { manufacturer }\end{array}$ & 9 & 1,4 & 2 & 0,5 \\
\hline Independent workshop & 72 & 11,2 & 51 & 13,1 \\
\hline Do own servicing repairs & 70 & 10,9 & 51 & 13,1 \\
\hline Backyard mechanic & 19 & 3,0 & 15 & 3,9 \\
\hline No specific dealer/garage & 8 & 1,3 & .5 & 1,3 \\
\hline Haven't decided yet & 26 & 4,1 & 49 & 12,6 \\
\hline Other & 2 & 0,3 & 1 & 0,3 \\
\hline No response & 20 & 3,1 & 20 & 5,1 \\
\hline Total & $642^{2}$ & 100,1 & $390^{3}$ & 100,2 \\
\hline
\end{tabular}

${ }^{1}$ All respondents included, warranty expired and warranty not expired.

${ }^{2} 642$ of the 657 respondents indicated that they will still possess the vehicle when it is less than five years old.

${ }^{3} 390$ of the 657 respondents indicated that they will still possess the vehicle when it is more than five years old. 
Table 8 Actual and intended patronage of franchised dealers at various vehicle ages

\begin{tabular}{|c|c|c|}
\hline Age of vehicle & Percentage & Difference \\
\hline Under warranty (Table 3) & 94,8 & $22,1^{\mathrm{a}}$ \\
\hline First year after warranty - actual (Table 5) & 72,7 & 7,9 \\
\hline Vehicle $<5$ years old (Table 7$)$ & 64,8 & $14,5^{\mathrm{a}}$ \\
\hline Vehicle $5+$ years old (Table 7) & 50,3 & \\
\hline
\end{tabular}

- Significant at $p<0,05$

franchised dealer of the manufacturer.

Using Tables 3, 5 and 7 as basis, a possible pattern of actual and expected (intended) patronage of franchised dealers at various age categories has been constructed and is reflected in Table 8.

Table 8 shows a decline from $94,8 \%$ of respondents who patronize a franchised dealer while their vehicle is under warranty to $50,3 \%$ who intend to patronize a franchised dealer of the same manufacturer when the vehicle is more than five years old.

The trends detected by Richardson \& Fogg (1970), Crandall (1970) and Pashigian (1961), viz. that warranty expiry results in a major shift away from franchised dealers for service and repair work and that the older the vehicle becomes the greater the probability that it will not be serviced by a franchised dealer, thus seem to hold true for the South African situation.

An attempt was made to establish whether the decline (difference) between the four time periods was significant. As the two groups compared (those who patronize a franchised dealer and those who do not) are related, a conservative test for differences in proportions was conducted. Confidence intervals at the 0,05 level were calculated for both proportions. As no overlapping was found the $22,1 \%$ decline after expiry of warranty (Table 8 ) and the $14,5 \%$ decline between the ages less than five years old and more than five years, could be described as significant (Table 8).

The study also investigated the relationship between satisfaction with service received while the vehicle was under warranty and (i) the model of the vehicle and (ii) the price of the vehicle.

No relationship was found between satisfaction with service and the model of the vehicle owned at the 0,05 level of confidence $\left(x^{2}=6,57 ; d f=10\right)$. The same holds true regarding the price of the vehicle owned $\left(x^{2}=4,99\right.$; $d f=6$ ). No motor manufacturer thus appear to deliver a superior repair service while newly sold vehicles are under warranty.

\section{Summary of findings}

The findings of this study are:

- the owners of new passenger vehicles patronize a franchised dealer of the manufacturer of their vehicle for servicing/repairs while the vehicle is under warranty;
- the owners of new passenger vehicles are generally satisfied with the service received from franchised dealers of the manufacturer while the vehicle is under warranty;

- a significant number of new vehicle owners shift their patronage for servicing/repairs away from a dealership of the manufacturer once the warranty has expired;

- a decreasing number of owners of new passenger vehicles intend patronizing a franchised dealer of the manufacturer as the age of the vehicle increases;

- there is no relationship between satisfaction with the service received while the vehicle is/was under warranty and (i) the price and (ii) the model of the vehicle.

\section{Limitations of the study}

A limitation of this study is that the researchers, endeavouring to investigate the patronage behaviour of new vehicle owners, required respondents to provide information on intended, future behaviour. Although studies focusing on purchase intentions have been reported (Wise \& Cox, 1980; Humphreys \& Kasulis, 1981), this approach may not be scientifically sound and results obtained must be interpreted in the light hereof.

\section{Implications}

It is apparent that a definite shift in patronage with regard to servicing/repairs occurs as the age of a vehicle increases. It has also been established that the shift is particularly severe immediately after the expiry of the warranty.

However, it appears as if the shift is not quite of the same magnitude as suggested by two leading manufacturers (Boshoff, 1986: 196). A possible reason may be that the technology used in modern passenger vehicles is of such a nature that consumers may increasingly insist on the more specialized service only franchised dealers can offer.

Of particular concern to motor manufacturers should be the contrast between the high level of satisfaction among respondents regarding servicing/repairs while the vehicle is under warranty, with the indication by almost half of those who hope to still own the vehicle when it is more than five years old, that they will no longer be patronizing a franchised dealer at that stage. Possible reasons for this decision warrant attention during future research.

\section{Notes}

1. Throughout this article, patronage refers to servicing/ repairs and dealer or dealership to a franchised dealer of a motor vehicle manufacturer. Franchised dealers are the only firms permitted to market new vehicles.

2. Intentions to use attorney advertising have been used as a surrogate for actual use. The authors stated that the cost of obtaining a sample of actual users would be prohibitive. See Humphreys \& Kasulis, 1981. 


\section{References}

Boshoff, C. 1986. Importance-performance analysis: A comparative study of motor repair service customers. $S$. Afr. J. Bus. Mgmt, vol.17, 196-201.

Biehal, G.J. 1983. Consumers' prior experiences and perceptions in auto repair choice. J. Market, vol. 40, Summer, 82-91.

Crandall, R.W. 1970. The decline of the franchised dealer in the automobile repair market. J. Bus., vol. 43, January, 19-30.

Du Plessis, P.J. 1986. Verbruikersgedrag by die aankoop van 'n motorvoertuig. Unpublished DBL Dissertation. Pretoria: University of South Africa.

Humphreys. M.A. \& Kasulis, J.J. 1981. Attorney Advertising. J. Advert. Res., vol. 21(6), December, 31-37.

Martilla, J.A. \& James, J.C. 1977. Importance-performance analysis. J. Market., January, 77-79.
Pashigan, B.P. 1961. The distribution of automobiles: An economic analysis of the franchise system. New York: Prentice-Hall.

Richardson. L. \& Fogg, D.N. 1970. Service patronage patterns and new product warranties: A study of automobiles. $J$. Bus. Res., July, 213-217.

Rousseau, G.G. 1977. 'n Bemarkingsnavorsingsondersoek na die koopmotiewe van motoreienaars in die Suid-Afrikaanse motorhandel. Humanitas, R.S.A., vol. 4-2.

Wise, G.L. \& Cox. M.L. 1980. A Longtitudinal analysis of new car purchase patterns and intentions (1977-1979) as affected by differing degrees of energy uncertainty. In: Developments in Marketing Science, vol. III, edited by Venkatakrishna, V.B. 1980. Proceedings of the Fourth Annual Conference of the Academy of Marketing Science. Dallas. Texas (April 30 - May 3). pp 1-4. 